DOI - 10.53571/NJESR 2021.2.8.44-52

\title{
A Political Study- Studying Factors Contributing To Political Turmoil In Kashmir Valley
} Javid Ahmad Bhat, Dr. Deepali Singh

Research Scholar, Supervisor

School of Humanities And Social Sciences

Department of Political Science

NIMS University

Jaipur

Rajasthan

\section{Emailid.javidbhatt@gmail.com}

\begin{abstract}
The political turmoil started after the partition of India in 1947 as both India and Pakistan claimed the entirety of the former princely state of Jammu and Kashmir. It was in 1989 when the insurgency was born, as an indigenous movement against the corrupt governance. Kashmir has become a conflict zone between India and Pakistan; that escalated them into three wars and several other armed skirmishes. The political turmoil has ruined the state, and has forced New Delhi to notify the erstwhile state of Jammu and Kashmir (J\&K) as a "disturbed area" and invoke controversial and draconian laws like the Armed Forces Special Powers Act (AFSPA) to maintain peace. Though New Delhi tried to occasionally reach out to Pakistan and even to Kashmir's over the years, but for some brief periods of hope, peace has not prevailed in the Kashmir Valley
\end{abstract}

Key words:- Political Turmoil India Pakistan, Dispute, Kashmir

\section{Introduction}

Kashmir valley is known as the paradise on the EARTH, not only because of its topography or the bounty of beautiful landscapes but also due to the existence of harmony and cordial relationships between the people of various sections and religions with least or no room for the differences on the basis of castes, colour or religion. Since the accession of Jammu \& Kashmir with India, Kashmir valley happened to be a zone of ever escalating tension as a result of state being recognized as a disputed territory between India and Pakistan, The hopes that the Kashmir valley would become a more peaceful place with time. Contrary, the number and intensity of violent conflicts has seen a further increase and Kashmir is the focal point of an acute regional dispute that has pitted India and Pakistan against one another ever since they gained their independence from Great Britain in 1947. Already, these bitter rivals have 
gone to war twice over Kashmir, leaving the state physically divided and heavily militarized. The eruption of massive anti Indian violence in Indian Kashmir in early 1990 has changed the dispute, worsening India Pakistan relations and lending even greater urgency to the search for settlement. The roots of the political turmoil are tied to a dispute over local autonomy. Democratic development was limited in Kashmir until the late 1970s and by 1988 many of the democratic reforms provided by the Indian government had been reversed and non-violent channels for expressing discontent were limited and caused a dramatic increase in support for insurgents advocating violent secession from India In 1987, a disputed State election $^{1}$ created a catalyst for the insurgency when it resulted in some of the state's legislative assembly members forming armed insurgent groups. n July 1988, a series of demonstrations, strikes and attacks on the Indian government began the Kashmir insurgency, which during the 1990s escalated into the most important internal security issue in India from 1989 onwards militancy in Kashmir had passed through various phases. It acquired a qualitatively new terrorist character.

\section{Objectives of the study}

Factors Responsible for Political Turmoil in Kashmir Valley.

\section{Research Methodology}

Based on secondary data secondary sources have been put forward to find out the reason of above mentioned content following things are used in this research paper example books, reports published studies, gazettes newspapers articles, and various online sources.

\section{Findings Of The Study}

This study found that factors were of different kinds responsible for political turmoil in Kashmir valley from time to time.

\section{Exodus of Kashmir Pandits}

For the first time after independence of India from the british rule. Kashmiri pandits found themselves abandoned to their fate, stranded with their own homes Since 1990, Kashmiri protest movements were created to voice Kashmir's disputes and grievances with the Indian government in the Kashmir valley with some Kashmiri separatists armed conflict with the Indian government based on the demand for self-determination Due to rising insurgency of militancy in the Kashmir Valley, Pundits were forced to flee the valley. They were targeted by militant groups such as the Jammu Kashmir liberation front they marched through the streets of the valley, terrorizing them no end. 
Gawkadal massacre took place in Srinagar when a mass protest rally was being carried out by the pro-freedom leaders in the Kashmir capital Srinagar. The Indian paramilitary troops of the central reserve police force opened fire on a group protesters over the bridge that connects Basant Bagh with Maisuma, in Srinagar, killing at least 52 people and injured 250 according to survivors and media reports. The major killing became known as the 'GawKadal massacre' and now is usually marked by a shutdown. The massacre was named after the Gawkadal Bridge in Srinagar, and has been described by some authors as "the worst massacre in Kashmiri history

Kargil war Kargil war known as also kargil conflict was an armed conflict fought between india and Pakistan over the region of Kashmir which last for months in the kargil district of Kashmir and elsewhere along the line of control Pakistani soldiers from Pakistani Kashmir infiltrated Jammu and Kashmir. During the winter season, Indian forces regularly move down to lower altitudes, as severe climatic conditions makes it almost impossible for them to guard the high peaks near the Line of Control. This practice is followed by both India and Pakistan Army. The terrain makes it difficult for both sides to maintain a strict border control over Line of Control. The insurgents took advantage of this and occupied vacant mountain peaks in the kargil range overlooking the highway in Indian Kashmir that connects Srinagar and Leh By blocking the highway, they could cut off the only link between the Kashmir Valley and Ladakh. This resulted in a large-scale conflict between the Indian and Pakistani armies. The final stage involved major battles by Indian and Pakistani forces, with India recapturing most of the territories held by Pakistani forces.

Alqaeda organisation Al-Qaeda was helping organise a campaign of terror in Kashmir to provoke conflict between India and Pakistan. Their strategy was to force Pakistan to move its troops to the border with India, hiding in northwestern Pakistan. US intelligence analysts say Al-Qaeda and Taliban operatives in Pakistan-administered Kashmir are helping terrorists trained in Afghanistan to infiltrate Indian-adinistered Kashmir In 2006 Al-Qaeda claim they have established a wing in Kashmir, which worried the Indian government. Indian Army Lieutenant General H.S. Panag, GOCin-C Northern Command, told reporters that the army has ruled out the presence of Al-Qaeda in Indian-administered Jammu and Kashmir.

\section{Pakistan's Role in the Kashmir Insurgency from the American RAND Corporation}

The nature of the Kashmir conflict has been transformed from what was originally a secular, locally based struggle (conducted via the Jammu Kashmir Liberation Front- JKLF) to one that is now largely carried out by foreign militants." The majority of militant organisations are composed of foreign mercenaries, mostly from the Pakistani Punjab In 2010, with the support of its intelligence agencies, Pakistan again 'boosted' Kashmir militants, and recruitment of militants in the Pakistani state of Punjab has increased. 


\section{Militant Attacks}

March 102008 people were wounded when a blast hit the region's only highway overpass located near the civil secretariat the seat of government of Indian controlled Kashmir and the region's high court. A gun battle broke between security forces and militants fighting against Indian rule left five people dead and two others injured on 23 March 2008. The battle began when security forces raided a house on the outskirts of the capital city of Srinagar housing militants. The Indian ARMY has been carrying out cordon-and-search operations against militants in Indian-administered Kashmir since the violence broke out in 1989. While the authorities say 43,000 people have been killed in the violence, various human rights groups and non-governmental organisations have put the figure at twice that number.According to the Government of India Home Ministry, 2008 was the year with the lowest civilian casualties in 20 years, with 89 deaths, compared to a high of 1,413 in 1996. In 2008, 85 security personnel died compared to 613 in 2001, while 102 militants were killed.

\section{Kashmir Protests Amarnath Land Transfer Controversy}

Amarnath Temple is a Hindu shrine located in Jammu and Kashmir, India. The cave is situated at an altitude of 3,888 m (12,756 ft) ${ }^{[1]}$ about $141 \mathrm{~km}$ (88 mi) from Srinagar, the summer capital of Jammu and Kashmir, reached through Pahalgam town. The shrine represents an important part of Hinduism, ${ }^{[2]}$ and is considered to be one of the holiest shrines in Hinduism. ${ }^{[3]}$ Hundreds of thousands of Hindus and other devotees make an annual pilgrimage to the Amarnath cave across challenging mountainous terrain. On June 172008 Two month long annual Amarnath pilgrimage begins Protests start in Ganderbal district of Kashmir valley and spread to many parts of the Kashmir valley. Massive protest started against allotment of 800 kanals land to Shri Amarnath Shrine in the Muslim-majority Kashmir valley. ${ }^{1}$ This land was to be used to build a shelter to house Hindu pilgrims temporarily during their annual pilgrimage to the Amarnath temple. Such demonstrations have been aloof of the fact that the India government very regularly undertakes activities for upliftment of Muslim community (as a secular government) and very regularly donates lands and other properties to the systemized Waqf Boards. Indian security forces and the Indian army responded quickly to keep order. More than 40 unarmed protesters were killed and at least 300 were detained. The largest protests saw more than a half million people waving Pakistani flags and crying for freedom at a rally on 18 August, according to Time Magazine Pro-independence Kashmiri leader Mirwaiz Umar Farooq warned that the peaceful uprising could lead to an upsurge in violence if India's heavy-handed crackdown on protests was not restrained. The United Nations expressed concern at India's response to peaceful protests and urged investigations be launched against Indian security personnel who had taken part in the crackdown. Separatists and political party workers were believed to be behind stonethrowing incidents, which have led to retaliatory fire from the police..

2008 Kashmir Elections Jammu and Kashmir state assembly elections and boycott 
State elections were held in Indian administered Kashmir in seven phases, starting on 17 November and finishing on 24 December 2008. In spite of calls by separatists for a boycott, an unusually high turnout of more than $60 \%$ was recorded The National Conference party, which was founded by Sheikh Abdullah and is regarded as pro-India, emerged with a majority of the seats. On 30 December, the Congress Party and the National Conference agreed to form a coalition government, with Omar Abdullah as Chief Minister. In March 2009, Abdullah stated that only 800 militants were active in the state and out of these only $30 \%$ were Kashmiris. The Union home ministry did its bit by not only providing the requisite Central forces over 700 companies for keeping vigil during the poll but also quietly restricting the movement and public appearances of key separatist leaders like Mirwaiz Omer Farooq and Syed Ali Shah Geelani while the poll process was on. This put the separatist issues on the back burner, enabling the $J \& K$ electorate to focus on what may well have been real issues like development and infrastructure

\section{Kashmir protests Arrest and Curfews}

In 2009, protests started over the alleged murder of two young women in Shopian in South Kashmir. Suspicion pointed towards the police as the perpetrators. A judicial enquiry by a retired High Court official confirmed the suspicion, but a CBI enquiry reversed their conclusion As soon as the news about the incident spread in the Kashmir valley, spontaneous protests started. These protests were followed by the strike call by the secessionist leaders. Demands for justice, self-determination and removal of the Indian forces started. As soon as the protests started, police and Indian armed forces in order to halt the protests batten charged the protesters and fired repeated tear gas canisters. Many separatist leaders were put under house arrest or jailed. This gave fresh impetus to popular agitation against India. Significantly, the unity between the separatist parties was lacking this time.

\section{Kashmir Unrest}

This year, Kashmir watchers said, may go down as one of the bloodiest in the state's history 2010 protests, a result of the death of 17-year-old Tufail Mattoo in police firing, left around 120 people dead. The 2010 Kashmir unrest was series of protests in the Muslim majority Kashmir Valley in Jammu and Kashmir which started in June 2010. These protests involved the 'Quit Jammu Kashmir Movement' launched by the Hurriyat Conference led by Syed Ali Shah Geelani and Mirwaiz Umar Farooq who had called for the complete demilitarisation of Jammu and Kashmir. The All Parties Hurriyat Conference made this call to protest, citing human rights abuses by Indian troops. Chief Minister Omar Abdullah attributed the 2010 unrest to the fake encounter staged by the military in Machil. Protesters shouted pro-independence slogans, defied curfews, attacked security forces with stones and burnt police vehicles and government buildings. The Jammu and Kashmir Police and Indian para-military forces fired live ammunition on the protesters, resulting in 112 deaths, including 
many teenagers. The protests subsided after the Indian government announced a package of measures aimed at defusing the tensions in September 2010.

\section{Execution Parliament Attack Convict.}

In 2013 huge rallies of protest started in various parts of Kashmir against the conviction of mohd afzal guru in tihar. Two other deaths took place in Sumbal belt, not far away from Srinagar. When a a group of youth protesting against the hanging when CRPF personnel chased them and the entire group fled and took refuge in a boat. When the paramilitary seized the boat, they jumped into the water. While most of them swam to ashore, two could not. While one body was fished out instantly another was recovered Monday afternoon as soon this news triggered in the valley thousands of protesters came out to protest .which not only took lives but this protest make everybody's life spillted in every phase.

\section{October 2014 cross border violation}

In October 2014, Indian and Pakistani troops traded gunfire over their border in the divided Himalayan region of Kashmir, killing at least four civilians and worsening tensions between the longtime rivals, officials on both sides have said. The small-arms and mortar exchanges - which Indian officials called the worst violation of a 2003 ceasefire - left 18 civilians wounded in Kashmir valley. Tens of thousands of people fled their homes on both sides after the violence erupted on 5 October. Official reports state seven in civilians were killed in three nights of fighting this whole trauma led another protest and curfews in the valley which remain for weeks huge number of protests start through the valley which lead another misery to the lives of people

\section{July 2016 Kashmir unrest}

On July 082016 a joint team of the special operations group of the Jammu and Kashmir Police and Rashtriya Rifles killed Burhan, A popular face of the militant group along with his two associates, in the Kokernag area IN Kashmir as the news of Wani's death triggered Thousands from different parts of the valley gathered to protest. Separatists took the opportunity to fuel passions and called for a three-day shutdown in Kashmir to protest against the killing. Violent clashes broke out in response to the killing on 9 July in some areas and stone pelting was also reported from many parts of Kashmir. In the following days, several police stations and security establishments were attacked and soon the Centre had to rush in thousands of paramilitary forces to contain the situation. By July 10, more confirmed to have died during the unrest and around 300 CRPF personnel were reported to have been injured. More than 600 have pellet injuries who may lose their eyesight With the situation spiralling out of control, the government imposed curfew in all districts of Kashmir on July 15 and all mobile phone services were restricted for months to stop the situation which lead a miserable condition to 
every aspect of the valley this long lasting protest was the worst agitation as it curb the whole system of the valley kashmir

\section{September 2016 Uri attack}

An attack by four militants on an Indian Army base on 18 September 2016, also known as the 2016 Uri attack resulted in the death of 19 soldiers as well as the militants themselves. Although no-one claimed responsibility for the attack, the militant group was suspected of involvement by the Indian authorities. The Indians were particularly shaken by the event which they blamed on Islamabad. Response took various forms, including the postponement of the 19th SAARC summit asking the Russian government to call off a joint military exercise with Pakistan, and the Indian Motion Picture Producers Association decision to suspend work with Pakistan. On the Pakistani side, military alertness was raised and some Pakistan International Airlines flights suspended. The Pakistani government "denied any role in cross-border terrorism, and called on the United Nations and the international community to investigate atrocities it alleged have been committed by the security forces in Indian-ruled Kashmir

\section{Abolition of Article 370}

Article 370 was a 'temporary provision' inserted on 17 October 1949 which gave special powers to the state of Jammu Kashmir lawfully authorising it to have its own constitution. Accordingly, the provisions of only Article 1 and Article 370 of the Indian Constitution applied to the state. So, for the Central government to extent the coverage of a central law to the state on subjects included in the instrument of accession (IoA), it needed "consultation" while for extending the coverage of laws on other subjects, it needed "concurrence" of the state government On 5 August 2019, the Government of India revoked the special status, granted under Article 370 of the Indian Constitution to Jammu and Kashmir - a region administered by India as a state which consists of the larger part of Kashmir which has been the subject of dispute among India, Pakistan, and China since 1947 The President of India issued an order under the power of Article 370, overriding the prevailing 1954 Presidential Order and nullifying all the provisions of autonomy granted to the state. The Home Minister introduced a Reorganisation Bill in the Indian Parliament, seeking to divide the state into two union territories to be governed by a lieutenant governor and a unicameral legislature. The resolution seeking the revocation of the special status under Article 370 and the bill for the state's reorganisation was debated and passed by the Rajya Sabah - India's upper house of parliament - on 5 August 2019. On 6 August, the Lok Sabah - India's lower house of parliament - debated and passed the reorganisation bill along with the resolution recommending the revocation. Among the Indian government actions accompanying the revocation was the cutting off of communication lines in the Kashmir Valley restored after 9 months. Thousands of security forces were deployed to curb any uprising. Several leading Kashmiri politicians were taken into custody, Government officials 
described these restrictions as designed for pre-empting violence, and justified the revocation for enabling people of the state to access government programmes such as reservation, right to education and right to information The reaction in the Kashmir Valley was effectively reduced to silence because of cut-off communication and with imposition of Curfew (Section 144). Newspapers have also been restricted in many parts of the state. To prevent volatile Many nationalists celebrated, declaring the move to herald public order and prosperity in Kashmir many opposed like the Indian National Congress, Jammu \& Kashmir National Conference, Jammu and Kashmir Peoples Democratic Party, Trina mol Congress,

\section{Conclusion}

It was in 1989 when the insurgency was born, as an indigenous movement against the corrupt governance and autocratic rule of Sheikh Abdullah. Externally, too, Kashmir has long been a bone of contention between India and Pakistan; the two countries have fought four wars over the valley. The insurgency has ruined the normal functioning of the state, and has forced New Delhi to notify the erstwhile state of Jammu and Kashmir (J\&K) as a "disturbed area" and invoke controversial and draconian laws like the Armed Forces Special Powers Act (AFSPA) to maintain peace. Though New Delhi tried to occasionally reach out to Pakistan and even to Kashmiris over the years, but for some brief periods of hope, peace has not prevailed in the Kashmir Valley. Following the precedent set by his predecessors, Atal Bihari Vajpayee and Manmohan Singh, Prime Minister Narendra Modi has also tried to reach out to Pakistan. But with the passage of time Pakistan has sponsored the different terrorist organizations in Kashmir. Pakistan affirmatively sticks to its policy of extending 'moral support' to the separatists in Kashmir. In such a state of affair, the common Kashmir's are suffering most. The innocent people are being victimized by baneful separatist propaganda. Confrontations between Indian military and armed separatists have caused huge loss of property, money, education sector and lives so far. As a result, Kashmir frequently witnessed violence, curfew, stone-pelting, and firing between the troops of India and Pakistan across Line of Control (LoC).Thousands of soldiers, civilians, and militants have been killed in the uprising and the Indian crackdown since 1989. The way to this conflict resolution lies in the methods of psychological intervention. Psychological perspective of the problem is more propound than its military, political, and diplomatic dimensions and interpretations. Pakistan must come forward to eradicate the terrorist organizations functional in Kashmir, and continue the bilateral talks Kashmir was and still is an integral part of India. It has a plural and secular culture - just like the rest of India. Urgent steps should be taken to bridge the gaps of trust deficit in the minds of Kashmiri youth. All Kashmiris should get the due share in the growth story of India. Like all other states in India, there should be adequate political autonomy in Jammu and Kashmir. Violence, terrorism, and killings are never the answer be it on any side. Article 370 provisions of the Constitution, which guaranteed special status to Jammu and Kashmir central government, has revoked it on august 5 - 
2019 and bifurcated the state into Union territories The Indian Government justified its action by saying that this will help end violence and militancy in the state and enable people to access government schemes such as reservation, right to education and right to information among other schemes. ${ }^{[7]}$ and has assured that this step will bring change in socio-economic development in both the new UT's of Jammu and Kashmir and Ladakh. Empowerment of people, removal of unjust laws, bringing in equity and fairness to those discriminated since ages who are now getting their due along with comprehensive development are some of the important changes that are ushering both the new UTs towards the path of peace and progress

\section{References}

- India matters sep 2019(ORF)

- Kashmir wala $21^{\text {st }}$ january1990 news agency Kashmir .com

- Flee-IDR Indian defence. Review by Col Dr Tejkumar Book excerpt Kashmir its aborigines and their exodus.

- Mori survey

- Govt of Indian home ministry

- 2008 Amarnath land Time magazine

- India news chronology of amaranth agitation jk

- Election 2008 the economic times. politics dec 2008 protest arrest and curfew

- 2010 unrest Hindustan times by toufiq Rashid

- https://economictimes.indiatimes.com//news/politics-and-nation/afzal-guru-hanged

- 2016 kashmir unrest.

- $\quad$ www.oneindia.com flash back 2016

- Art-ORF jan 28.2020 issue briefs and special reports

- Kashmir after article 370 indias diplomatic challenge by Khalid shah kriti $\mathrm{m}$ shah 